\title{
ANALISIS STRUKTUR INDUSTRI SUSU DI INDONESIA
}

\author{
Ihwan Susila \\ Universitas Muhammadiyah Surakarta
}

\begin{abstract}
Decision for a strategy needs circumstantial analysis from environment of external and internal situation. There are two important situations which need considered. First, industrial condition and its emulation. Second, company capability to compete, resource, strength and internal feebleness, and the market position. All peripatetic organization in macro environment having major effect to company strategy. Such macro environment according to Thompson and Stricland (2003) for example: free economics, demography, social values and the life style, legislation and governmental regulation, and the technological factors. From other side macro environment, a business organization given on by environment of emulation and direct interconnected industry with company. According to Porter (1980), there are five very strength have an effect on to determination of company strategy in a industry in order to earn to own competing excellence that is: suppliers, new comer in industry, buyer, company of competitor and other; dissimilar company offering substitute product. The factors give pressures in emulation which influence compared by stronger of other macro factor industrial growth of milk in Indonesia nor quit of factors or strength and emulation pressures. During the time productivity of raw material of milk that is fresh milk in Indonesia still be pertained by lower, so that not yet earned to fulfill national requirement.
\end{abstract}

Keywords: industrial condition, milk industries, strategies

\section{PENDAHULUAN}

Keputusan atas suatu strategi memerlukan analisis yang mendalam dari lingkungan eksternal dan situasi internal. Terdapat dua situasi penting yang perlu dipertimbangkan. Pertama, kondisi industri dan persaingannya. Kedua, kapabilitas perusahaan untuk bersaing, sumber daya, kekuatan dan kelemahan internal, dan posisi pasar. Semua organisasi bergerak dalam suatu lingkungan makro yang mempunyai pengaruh besar terhadap strategi perusahaan. Lingkungan makro yang dimaksud menurut Thompson dan Stricland (2003) antara lain: ekonomi bebas, demografi, nilainilai sosial dan gaya hidup, perundangundangan dan peraturan pemerintah, dan faktor-faktor teknologi.

Di samping lingkungan makro, sebuah organisasi bisnis dihadapkan pada lingkungan persaingan dan industri yang berkaitan langsung dengan perusahaan. Menurut Porter (1980), terdapat lima kekuatan yang sangat berpengaruh terhadap penentuan strategi perusahaan dalam sebuah industri agar dapat memiliki keunggulan bersaing yaitu: suppliers, pendatang baru dalam industri, pembeli, perusahaan pesaing dan perusahaan lain yang menawarkan produk pengganti. Faktor-faktor tersebut memberikan tekanan-tekanan dalam persaingan yang péngaruhnya lebih kuat dibandingkan dengan faktor makro lainnya. 
Perkembangan industri susu di Indonesia juga tidak terlepas dari faktor-faktor atau kekuatan dan tekanan-tekanan persaingan. Selama ini produktivitas bahan baku susu olahan yaitu susu segar di Indonesia masih tergolong rendah, sehingga belum dapat memenuhi kebutuhan nasional. Produksi susu nasional sebagai bahan baku industri pengolahan susu saat ini hanya mengandalkan 100 ribu peternak dan 338 ribu sapi dengan skala rata-rata 3 ekor per kepala keluarga. Produktivitas ternak tersebut sekitar 9-10 liter per ekor setiap harinya. Sedangkan $60 \%$ produksi di tingkat KUD masih di bawah 5.000 liter per hari. Jumlah tersebut terkonsentrasi di pulau Jawa yang sebenarnya lahan bagi kepentingan ternak sapi semakin menyempit.

Di sisi lain kebutuhan akan konsumsi susu, terus mengalami peningkatan seiring dengan peningkatan perbaikan kondisi ekonomi Indonesia setelah mengalami krisis ekonomi tahun 1997. Kebutuhan susu nasional menurut proyeksi PT. Sari Husada, salah satu produsen susu bayi dan susu olahan di Indonesia mencapai 1.700 .000 ton pada tahun 2003 dan diperkirakan meningkat menjadi 2.000.000 ton pada tahun 2004. Sedangkan produksi susu segar sebagai bahan baku susu bayi dan susu olahan hanya sekitar 500.000 ton pada tahun 2003 dan pada tahun 2004 diperkirakan sebesar 600.000 ton.

Tulisan ini akan membahas tentang perkembangan industri susu nasional baik dari struktur industrinya, lingkungan yang berpengaruh terhadap industri ini, peluang dan ancamannya serta penyusunan dan pilihan strategi yang akan diterapkan untuk memperoleh keunggulan kompetitif. Pada bagian awal akan dijelaskan tentang kondisi umum industri susu di Indonesia. Bagian selanjutnya berupa analisis struktur industri susu berdasarkan konsep dari Porter tentang the five competitif force model dan diakhiri dengan pembentukan strategi kompetitif untuk meningkatkan keunggulan bersaing.

\section{KONDISI UMUM INDUSTRI}

Industri susu termasuk salah satu industri yang banyak menganut sistim lisensi dengan kontrak produksi. PT. Tigaka misalnya, yang dulunya sebagai importir susu merk Dumex, sejak 1991 dipercaya oleh Int'l Nutrition Coy. untuk memegang lisensinya. Sedangkan produksinya dilakukan oleh PT. Sari Husada. Demikian pula dengan PT. Eurindo Combined yang dipercaya oleh Lyempf Belanda, sejak 1989, untuk memegang lisensi dengan salah satu produk terkenal Bebelac (susu bubuk bayi) yang produksinya dilakukan oleh PT. Nutricia Sejahtera Indonesia (Salim Grup).

Sementara itu, data Gabungan Koperasi Susu Indonesia (GKSI) menunjukkan bahwa industri susu menyerap sekitar 80\% (sekitar 200 juta liter) dari total produksi susu milik GKSI dengan pertumbuhan yang rata-rata $120 \%$ per tahun sejak 1997 , setahun setelah berdirinya GKSI (Juli 1978). Tahun 1977, produksi GKSI hanya 1,3 juta liter naik menjadi 250 juta liter pada tahun 1989 dengan dukungan 74.000 peternak dan 190 koperasi susu. Sampai dengan tahun 1992, jumlah koperasi yang bergabung dengan GKSI sebanyak 201 koperasi dengan 80.000 peternak yang memiliki 325.000 ekor sapi perah. Produksinya juga naik menjadi 290 juta liter. GKSI sendiri juga memasarkan produk susu murni (pasteurisasi dan homogenisasi) dengan merk Alam Murni menggunakan distributor utama.PT. Globe Enterprises.

Menurut data BPS tahun 2001, jumlah ternak sapi perah (penghasil susu segar) mencapai 368.500 ekor. Jumlah ini meningkat dibanding tahun 1997 sebanyak 334.400 ekor. Jumlah tersebut menurun pada tahun 1998 menjadi 322.000 ekor sampai dengan tahun 1999. Populasi ternak sapi perah mulai meningkat pada tahun 2000 yaitu mencapai 354.000 ekor. Kondisi tersebut cukup mengembirakan, karena peningkatan jumlah atau populasi ternak sapi perah akan mampu meningkatkan pasokan susu segar bagi industri susu olahan nasional. Data selengkapnya 
mengenai jumlah ternak sapi perah dan beberapa ternak lainnya ditunjukkan pada tabel 1.

Kebijakan menerapkan rasio impor susu dengan daya serap lokal, mampu meningkatkan taraf hidup peternak dan menghemat devisa. Pada tahun 1977, impor susu diperbolehkan sampai dengan $100 \%$. Sejak terbentuknya GKSI, mulai dinetralisir dengan rasio 1:20 yang terus direvisi sehingga kini menjadi $1: 1,7$. Artinya jika produsen susu menyerap 1 juta liter susu lokal maka diijinkan mengimpor 1,7 juta liter susu. Tata niaga juga mengatur bahwa yang menjadi importir bahan susu adalah importir produsen sedangkan untuk susu jadi hanya oleh 2 persero niaga. Total impor bahan susu dan preparat lainnya, tahun 1992 mencapai US\$ 91 juta naik pesat dari tahun 1991 US\$ 63,6 juta.
Industri susu nasional memiliki potensi pasar yang besar di samping beberapa bentuk proteksi yang ada misalnya dukungan kuat untuk membantu susu nasional dari serbuan industri susu asing (impor). Menentukan susu dan sasaran kelas konsumen memang akhirnya merupakan langkah terpenting apalagi pemerintah dan WHO melarang kegiatan promosi via media massa untuk susu bayi di bawah usia 6 bulan, sehingga wajar jika banyak produsen susu yang memasarkan (atau perkenalan perdana) kepada ibu-ibu secara tidak langsung melalui rumah bersalin atas kebijaksanaan dokter. Bayi sebagai konsumen potensial telah digarap secara mantap dengan 3 pangsa yakni infant (0-6 bulan), follow on formula (0,5 tahun sampai 4 tahun) dan susu untuk pertumbuhan. Selain itu masih terdapat 8 jenis susu lainnya yang dipasarkan di Indonesia.

Tabel 1. Populasi Ternak di Indonesia Tahun 1997 - 2001

Livestock Population 1997 - 2001 (Indonesia)

(000 head)

\begin{tabular}{|c|c|c|c|c|c|c|}
\hline \multirow[t]{2}{*}{ No. } & \multirow[t]{2}{*}{ Species } & \multicolumn{5}{|c|}{ Year } \\
\hline & & 1997 & 1998 & 1999 & 2000 & 2001") \\
\hline $\mathbf{I}$ & RUMINANT & & & & & \\
\hline 1. & Beef cattle & $11,938.9$ & $11,633.9$ & $11,275.7$ & $11,008.0$ & $11,191.7$ \\
\hline 2. & Dairy cattle & 334.4 & 322.0 & 332.0 & 354.3 & 368.5 \\
\hline 3. & Buffaio & $3,064.5$ & $2,829.3$ & $2,503.8$ & $2,405.3$ & $2,287.2$ \\
\hline 4. & Goat & $14,162.5$ & $13,560.5$ & $12,701.4$ & $12,565.6$ & $12,456.4$ \\
\hline 5. & Sheep & $7,697.7$ & $7,144.0$ & $7,225.7$ & $7,427.0$ & $7,294.3$ \\
\hline II & NON RUMINANT & & & & & \\
\hline 1. & $\mathrm{Pig}$ & $8,232.8$ & $7,797.6$ & $7,041.8$ & $5,356.8$ & $5,866.8$ \\
\hline 2. & Horse & 582.3 & 566.5 & 484.3 & 412.4 & 430.4 \\
\hline III & POULTRY & & & & & \\
\hline 1. & Native chicken & $260,834.7$ & $253,133.4$ & $252,653.3$ & $259,256.6$ & $262,630.9$ \\
\hline 2. & Layer & $70,622.8$ & $38,861.3$ & $45,530.8$ & $69,366.0$ & $66,927.8$ \\
\hline 3. & Broiler & $641,373.8$ & $354,003.5$ & $324,346.8$ & $530,874.1$ & $524,272.9$ \\
\hline 4. & Duck & $30,320.0$ & $25,950.0$ & $27,552.0$ & $29,035.3$ & 29,904 . \\
\hline
\end{tabular}

Source: Directorate General of Livestock Services, 2001 Note: ") Preliminary figures up to May 2001 
Meningkatnya jumlah penduduk dan berubahnya pola konsumsi serta angka kelahiran yang stabil merupakan potensi pasar dimasa datang. Berdasarkan data Dirjen Peternakan, secara keseluruhan kebutuhan susu nasional per tahun mecapai 1.248 ribu ton dengan tingkat pertumbuhan $11,7 \%$. Sedangkan produksi susu segar dalam negeri hanya 387 ribu ton dengan pertumbuhan $8,3 \%$ per tahun. Keterbatasan pasokan bahan baku lokal menyebabkan pemakaian bahan baku impor cukup banyak dan menyebabkan harga susu meningkat tajam. Data sampai dengan tahun 1999, harga susu di Indonesia mengalami peningkatan yang cukup signifikan. Tahun 1994, harga susu dari peternak sebesar Rp. 615 ,- per liter menjadi Rp. 1.125 ,- pada tahun 1999.

Kemitraan antara produsen dan peternak atau koperasi susu perlu dilakukan untuk meningkatkan produksi susu lokal sehingga ketergantungan impor dapat dikurangi. Dirjen Peternakan Departemen Pertanian, menyatakan bahwa pemerintah pada awal tahun 1997 mulai merintis upaya pengembangan industri sapi perah di luar Pulau Jawa. Hal ini dilakukan agar produksi susu nasional dapat meningkat dan hasilnya mampu memenuhi kebutuhan bahan baku untuk produsen susu bayi dan olahan. Melalui program tersebut diharapkan produksi susu nasional dapat meningkat sebesar $10 \%$.

Melihat upaya tersebut, tampaknya ada titik cerah dalam upaya pengadaan bahan baku susu. Namun demikian masih banyak kendala yang dihadapi, antara lain masih sederhananya teknologi atau cara beternak dan bahan pakan sapi berupa konsentrat yang masih harus didatangkan dari luar negeri.

Ketergantungan pada bahan baku susu impor masih cukup besar. Jika diasumsikan pertumbuhan pengadaan susu segar $2 \%$ per tahun maka produksi susu segar nasional masih jauh dari target kebutuhan nasional. Dengan demikian, produksi susu segar nasional tetap tidak akan dapat memenuhi kebutuhan produsen susu bayi dan olahan untuk lima tahun mendatang. Bahan baku susu impor masih akan mendominasi suplai bahan baku susu bayi dan olahan.

\section{STRUKTUR INDUSTRI SUSU DI INDONESIA}

Saat ini terdapat tujuh perusahaan yang memproduksi susu bayi dengan kapasitas sebesar 110.256 ton susu bayi berbentuk bubuk. Kapasitas produksi terbesar untuk susu bayi adalah PT. Sari Husada dengan kapasitas $32.956 .000 \mathrm{~kg}$ susu bubuk untuk bayi. Selanjutnya PT. Nutricia Sejahtera Indonesia dengan kapasitas $22.500 .000 \mathrm{~kg}$, disusul PT Nestle Indonesia, Sugizindo, PT. Friesche Vlag, Mirota Ksm, dan PT. Gizindo Primanusantara. Jumlah pemain dalam industri yang tidak banyak dan hanya beberapa yang menguasai pasar menyebabkan kompetisi untuk industri susu bayi bersifat oligopoli Tabel 2 menunjukkan produsen susu bayi dengan kapasitas dan jenis produksinya sampai dengan tahun 1996.

Dengan kapasitas produksi yang mencapai 110.206 ton, tingkat utilisasi industri susu bayi masih rendah. Hal ini didukung oleh data CIC tahun 1993 yang menyebutkan utilisasi seluruh industri susu di Indonesia memang rendah dibanding industri lainnya yaitu sebesar $33 \%$.

Meskipun tingkat utilisasi produksi susu bayi rendah, perkembangan produksi susu bubuk termasuk susu bayi selalu meningkat. Peningkatan ini lebih banyak didukung oleh perkembangan teknologi yang mampu meningkatkan kapasitas produksi dengan biaya yang efisien. 
Tabel 2. Produksi Daging, Telur, dan Susu tahun 1990 - 2001 / Meat, Egg and Milk Production 1990-2001 (Indonesia)

(000 ton)

\begin{tabular}{|c|c|c|c|c|}
\hline No. & Year & Meat & Egg & Milk \\
\hline 1. & 1990 & $1,027.7$ & 484.0 & $\mathbf{3 4 5 . 6}$ \\
\hline 2. & 1991 & $1,099.2$ & 510.4 & $\mathbf{3 6 0 . 2}$ \\
\hline 3. & 1992 & $1,239.2$ & 572.3 & 367.2 \\
\hline 4. & 1993 & $1,378.3$ & 572.9 & $\mathbf{3 8 7 . 5}$ \\
\hline 5. & 1994 & $1,492.9$ & 668.6 & $\mathbf{4 2 6 . 7}$ \\
\hline 6. & 1995 & $1,507.1$ & 736.0 & $\mathbf{4 3 3 . 4}$ \\
\hline 7. & 1996 & $1,632.2$ & 779.8 & $\mathbf{4 4 1 . 2}$ \\
\hline 8. & 1997 & $1,555.1$ & 765.0 & $\mathbf{4 2 3 . 7}$ \\
\hline 9. & 1998 & $1,228.5$ & 529.8 & $\mathbf{3 7 5 . 4}$ \\
\hline 10. & 1999 & $1,192.0$ & 640.1 & $\mathbf{4 3 6 . 0}$ \\
\hline 11. & 2000 & $1,445.2$ & 783.3 & $\mathbf{4 9 5 . 6}$ \\
\hline 12. & $\left.2001^{*}\right)$ & $1,450.7$ & 793.8 & $\mathbf{5 0 5 . 0}$ \\
\hline
\end{tabular}

Source: Directorate General of Livestock Services, 2001 Note : ) Preliminary figures up to May 2001

Jumlah produksi susu sampai dengan tahun 2001 mencapai 505.000 ton atau meningkat sebesar $40 \%$ dari tahun 1990. Perkembangan jumlah produksi yang selalu meningkat setiap tahunnya akan menjadikan industri susu di Indonesia mampu bertahan bahkan pada masa yang akan datang prospek industri susu nasional cukup prospektif

Sedangkan industri pengolahan susu olahan sendiri mulai berkembang sejak tahun 1970an. Hal tersebut didukung oleh peningkatan ekonomi masyarakat dan budaya kesehatan. Saat ini terdapat sekitar 15 perusahaan yang bergerak dalam industri pengolahan susu dan kesemuanya beroperasi di Pulau Jawa dengan kapasitas produksi mencapai 1.881 juta ton ekuivalen dengan susu segar. Tabel 3, menunjukkan produsen susu olahan menurut kapasitas dan jenisnya sampai dengan tahun 1999.

Keberadaan industri susu bayi di Indonesia juga terkait dengan perkembangan perdagangan dunia. Hal ini terkait dengan pengadaan bahan baku susu termasuk susu bayi yang dua pertiganya masih harus didatangkan dari luar negeri. Impor susu Indonesia berasal dari berbagai negara antara lain Selandia Baru, Australia, Polandia, dan Jerman. Tabel 4 menunjukkan jumlah impor susu Indonesia.

Tabel 3. Produsen Susu Olahan Menurut Kapasitas dan Jenisnya Sampai dengan Tahun 1999

\begin{tabular}{lrrrr}
\hline \multicolumn{1}{c}{ Name of company } & SKM & SB & \multicolumn{1}{c}{ SC } & PL. \\
\hline PT. Friesche Vars \\
PT. Indomilk & 30,490 & 25,000 & 1,600 & 0 \\
PT. Nestle Indonesia & 55,262 & 0 & 3,081 & 4,500 \\
PT. Sari Husada & 38,112 & 61,500 & 5,600 & 12,000 \\
PT. Ultra Jaya & 10,000 & 8,800 & 0 & 0 \\
PT. Foremost Indonesia & 1,000 & 3,000 & 20,000 & 5,500 \\
Others & 2,924 & 0 & 10,500 & 0 \\
$\quad 25,300$ & & 379,033 & 175,499 & 200,274 \\
\hline Total & & & & \\
\hline
\end{tabular}

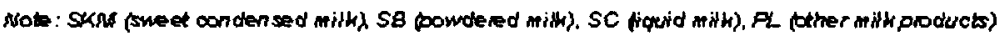

Source : Depantment of hidustry and Trade / Data Conalt 
a: 1):

Tabel 4. Impor Susu Indonesia dari Beberapa Negara Tahun 1998

\begin{tabular}{|c|c|c|c|}
\hline Year & Volume (tons) & Growth (Y) & Value (ISS $\$ 000$ ) \\
\hline 1992 & 44,321 & - & 77,677 \\
\hline 1993 & 41,796 & -5.7 & 80,646 \\
\hline 1994 & 48,693 & 16.5 & 80,222 \\
\hline 1995 & 65,464 & 34.4 & 143,157 \\
\hline 1996 & 51.705 & -21.0 & 114,432 \\
\hline 1997 & 48,783 & -6.0 & 94,371 \\
\hline 1998 *) & 36,970 & - & 64,643 \\
\hline
\end{tabular}

\section{ANALISIS STRUKTUR INDUSTRI}

Keputusan suatu strategi yang tepat memerlukan sebuah analisis, baik situasi eksternal maupun internal perusahaan. Setelah melakukan analisis situasi eksternal dan internal, langkah selanjutnya adalah mengevaluasi alternatif-alternatif yang ada kemudian memilih strategi yang tepat. Ketepatan mendiagnosa situasi perusahaan memerlukan persiapan managerial untuk memutuskan arah jangka panjang, menentukan tujuan yang tepat dan memenangkan strategi.

Semua industri memiliki perbedaan dalam karakteristik ekonomi, situasi persaingan dan prospek keuntungan di masa yang akan datang. Analisis industri dan kompetitif pada dasarnya menggunakan konsep dan teknik untuk mendapatkan ciri kunci industri yang jelas dan pasti. Selain itu, analisis industri juga digunakan untuk mengetahui tingkat persaingan, penggerak perubahan pada industri, posisi pasar dan strategi dari perusahaan lawan, kunci untuk sukses dalam persaingan dan keuntungan industri yang diharapkan.

Inti pokok formulasi strategi kompetitif sebenarnya adalah menghubungkan industri dengan lingkungan yang ada di sekitarnya.
Meskipun definisi lingkungan industri sangat luas, termasuk di antaranya kondisi sosial dan tekanan-tekanan ekonomi dari luar industri, namun dapat dipastikan bahwa lingkungan industri atau bisnis adalah industries in which it competes. Menurut Porter (1985), tingkat kompetisi dalam industri ditentukan oleh lima kekuatan mendasar yang disebut sebagai the five competitive force.

Dengan adanya berbagai tekanan kompetisi dalam industri, maka dapat ditentukan komponen kunci dari industri tersebut. Hal tersebut akan menunjukkan tingkat kekuatan persaingan yang ada di sektor industri serta peluang industri dalam memperoleh tingkat keuntungan (profitability level)

Lima kekuatan tersebut adalah pesaing potensial (potential entrants), pemasok (supplier), industri yang menyediakan barang atau jasa penganti (substitution), kekuatan pembeli (buyer), dan persaingan antar perusahaan dalam industri. Kelima kekuatan tersebut dapat dilihat pada gambar 1. 


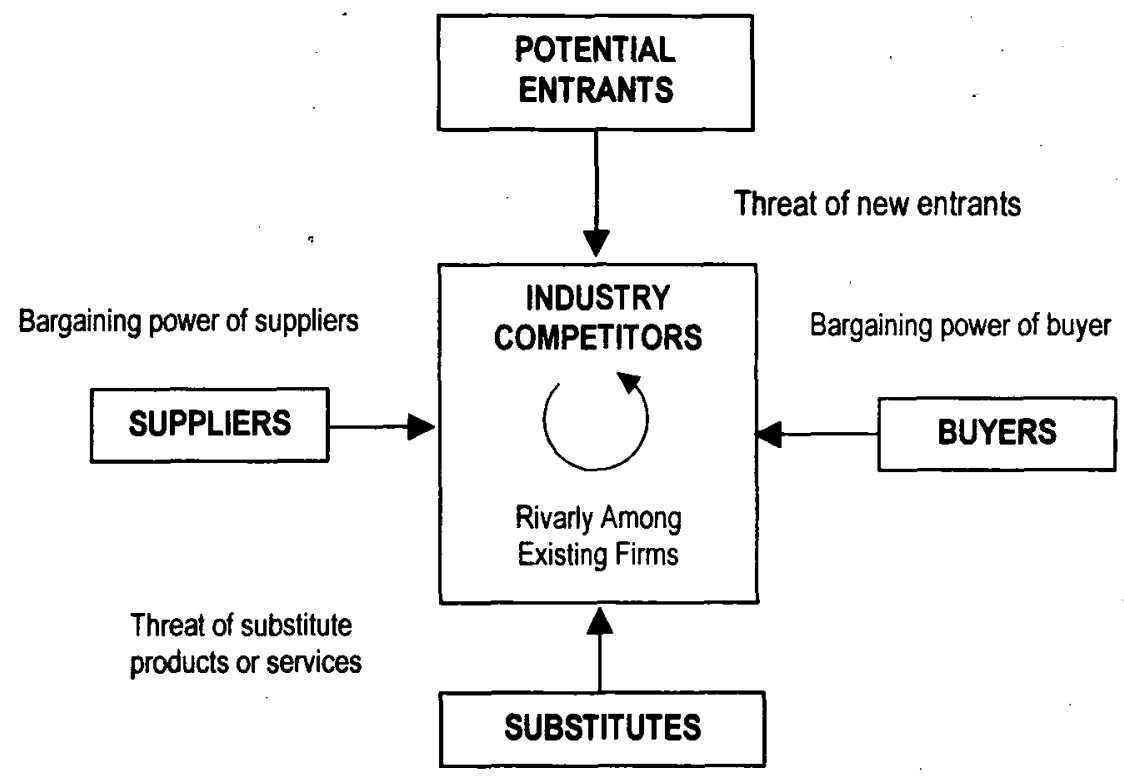

Gambar 1. Force Driving Industry Competition

\section{Kekuatan Tawar-Menawar Pembeli (Buyers)}

Pembeli tingkat pertama untuk produk susu biasanya pembeli terpusat atau pembeli dengan jumlah besar. Dalam industri susu bayi dan susu olahan, kelompok pembeli terpusat merupakan pembeli yang penting. Pembeli terpusat ini adalah kelompok retail, seperti toko-toko, supermarket, grosir, dan lain-lain. Kelompok pembeli terpusat lainya adalah outlet medis, seperti rumah sakit dan rumah bersalin. Pembeli ini mempunyai posisi yang cukup penting bagi perusahaan. Selain sebagai pembeli yang membeli dalam jumlah besar, pembeli ini juga merupakan saluran distribusi untuk pengguna akhir.

Menurut data konsultan PT. Holdiko Perkasa, terjadi penurunan jumlah konsumsi susu dari tahun 1994 sampai dengan 1998 yang ditunjukkan pada tabel 5 di bawah ini.

Tabel 5. Konsumsi Susu Perkapita Penduduk Indonesia

\begin{tabular}{ccccc}
\hline Year & $\begin{array}{c}\text { National } \\
\text { consumption } \\
\text { (tons) }\end{array}$ & $\begin{array}{c}\text { Population } \\
\text { (million people) }\end{array}$ & $\begin{array}{c}\text { Percapita } \\
\text { consumption } \\
\text { (kg) }\end{array}$ & $\begin{array}{c}\text { Growth } \\
\text { (\%) }\end{array}$ \\
\hline 1994 & 998.1 & 192.1 & 5.2 & - \\
\hline 1995 & $1,126.0$ & 195.5 & 5.8 & 11.5 \\
\hline 1996 & $1,263.4$ & 198.8 & 6.4 & 10.3 \\
\hline 1997 & $1,010.1$ & 202.1 & 4.9 & $(23.4)$ \\
\hline 1998 & 940.2 & 205.5 & 4.6 & $(6.1)$ \\
\hline
\end{tabular}


Tabel 7. Kebutuhan Masyarakat akan Makanan Berprotein Tinggi

\begin{tabular}{|l|l|r|r|r|r|c|}
\hline \multirow{2}{*}{ No. } & \multirow{2}{*}{ Commodity Group } & \multicolumn{5}{|c|}{ Protein ( gram ) } \\
\cline { 2 - 7 } & & $\mathbf{1 9 8 7}$ & $\mathbf{1 9 9 0}$ & 1993 & $\mathbf{1 9 9 6}$ & 1999 \\
\hline 1. & Cereals & 24.14 & 24.08 & 23.26 & 27.03 & 25.04 \\
\hline 2. & Tubers & 0.93 & 0.88 & 0.81 & 0.44 & 0.43 \\
\hline 3. & Fish & 6.23 & 7.01 & 7.26 & 7.16 & 6.07 \\
\hline 4. & Meat & 1.20 & 1.31 & 1.40 & 2.52 & 1.33 \\
\hline 5. & Eggs \& Milk & 1.36 & 1.33 & 1.67 & 2.07 & 1.43 \\
\hline 6. & Vegetables & 2.87 & 2.85 & 2.63 & 2.43 & 2.23 \\
\hline 7. & Legumes & 4.40 & 4.65 & 4.97 & 5.08 & 4.81 \\
\hline 8. & Fruits & 0.46 & 0.51 & 0.43 & 0.41 & 0.33 \\
\hline 9. & Others consumption & 2.41 & 2.71 & 2.87 & 2.79 & 2.4 \\
\hline
\end{tabular}

dapat dipenuhi oleh produsen dalam negeri menyebabkan industri pengolahan susu harus mengimpor bahan bakunya dari luar negari. Adanya keputusan pembebasan tarif impor susu memudahkan produsen susu dan makanan bayi untuk mendapatkan bahan baku. Namun demikian, harga bahan baku impor masih lebih mahal dibandingkan harga bahan baku lokal. Batasan atau kuota atas impor bahan baku susu dari luar negeri merupakan kendala bagi industri pengolahan susu bayi untuk mengimpor bahan baku selama persediaan lokal masih ada.

Data populasi ternak, termasuk sapi perah, penghasil susu segar sebagai bahan baku susu olahan masih kecil. Hal ini menyebabkan terbatasnya pasokan susu segar bagi industri susu olahan di Indonesia. Sampai dengan tahun 2001, jumlah ternak sapi perah masih tergolong kecil dibandingkan dengan populasi ternak lainnya, seperti nampak pada tabel berikut ini.

Data dari Biro Pusat Statistik menunjukkan kecilnya populasi ternak sapi perah dibandingkan dengan populasi hewan ternak lainnya, seperti nampak pada Tabel 8.

Ketergantungan terhadap bahan baku lokal tersebut menyebabkan kekuatan tawar- menawar pemasok terutama untuk pemasok dalam negeri meningkat. Perlu diingat bahwa para pemasok susu segar juga sulit menjual produknya ke industri lain. Adanya saling keterkaitan ini menyebakan kekuatan tawarmenawar antara pemasok dan produsen cenderung seimbang bahkan pemasok memiliki kekuatan yang lebih besar.

\section{Kemungkinan produk substitusi (subsitutions)}

Produk susu yang dihasilkan oleh industri susu bayi berasal dari susu sapi. Kelebihan dari susu sapi adalah kapasitas produksi yag cukup besar dari pemasok dan masih memungkinkan dikembangkan atau ditingkatkan lagi dengan penerapan teknologi yang lebih maju. Saat ini telah dikembangkan industri susu dari bahan baku kedelai. Susu kedelai mempunyai kandungan bahan nabati mendekati susu murni. Susu sapi mengandung 22 jenis asam amino dan 8 jenis amino esensial. Sementara susu kedelai, tidak mengandung asam amino esensial. Dengan demikian, dari sudut pandang kandungan gizinya, susu sapi lebih baik dibanding susu kedelai. Secara komersial, susu kedelai kurang ekonomis, di samping kualitasnya tidak sebaik susu sapi. Masyarakat juga kurang antusias dalam mengkonsumsi 
Tabel 8. Populasi Ternak / Livestock Population ( 000 Head)

\begin{tabular}{|l|l|l|l|l|}
\hline Kind of livestock & $\mathbf{1 9 9 8}$ & $\mathbf{1 9 9 9}$ & $\mathbf{2 0 0 0}$ & $\mathbf{2 0 0 1}$ \\
\hline Milking cows & 322 & 332 & 354 & 368 \\
\hline Cattle & 11,634 & 11,276 & 11,008 & 11,192 \\
\hline Buffaloes & 2,829 & 2,504 & 2,405 & 2,287 \\
\hline Horses & 566 & 484 & 412 & 430 \\
\hline Goats & 13,560 & 12,701 & 12,566 & 12,456 \\
\hline Sheep & 7,144 & 7,226 & 7,427 & 7,294 \\
\hline Pi g & 7,798 & 7,042 & 5,357 & 5,867 \\
\hline Local chickens & 267,898 & 256,653 & 259,257 & 262,631 \\
\hline Layer & 38,861 & 45,531 & 69,366 & 66,928 \\
\hline Broiller & 354,003 & 324,347 & 530,874 & 524,273 \\
\hline Ducks & 25,950 & 27,552 & 29,035 & 29,905 \\
\hline
\end{tabular}

Source: Directorate General of Livestock

susu kedelai. Dengan demikian kekuatan tawar-menawar produk substitusi lemah.

Produk-produk makanan yang mengandung protein tinggi juga merupakan bagian dari produk subtitusi susu. Produk-produk tersebut antara lain keju dan mentega. Namun demikian, produk-produk tersebut dianggap kurang memberi tekanan pada produk susu cair maupun susu bubuk sebagai barang pengganti susu.

\section{Kemungkinan masuknya pemain baru (potential entrants)}

Dalam industri susu bayi, terdapat rintangan masuk yang ditemui oleh pendatang baru. Pencapaian skala ekonomi bagi pendatang baru harus memperoleh tingkat efisiensi dalam biaya produksi dengan melakukan produksi dan penjualan secara besar-besaran. Hal tersebut sulit dilakukan karena adanya pemain lama yang telah menguasai pasar. Selain itu akses untuk memperoleh bahan baku terutama susu segar lokal sulit dilakukan karena biasanya industri yang sudah ada telah menjalin kerjasama atau kemitraan dengan produsen susu segar, sedangkan impor susu saat ini relatif mahal. Dengan demikain jika pendatang baru tidak memiliki keterkaitan dengan sumber bahan baku baik lokal maupun impor, akan sulit menghasilkan produk dengan harga bersaing.

Meskipun demikian, produk-produk luar negeri yang akan masuk secara bebas setelah AFTA dan NAFTA diberlakukan, akan menjadi pemain yang potensial mengancam keberadaan industri susu nasional. Beberapa perusahaan dari berbagai negara akan memanfaatkan kesempatan tersebut untuk meraih sebagian pasar yang belum terlayani produsen dalam negeri. Perusahaanperusahaan tersebut antara lain berasal dari Jepang, Thailand, dan Australia

Hal lain yang menjadi penghalang adalah produk susu bayi cukup terdiferensiasi. Produsen susu bayi sudah mempunyai identitas merek dan kesetiaan pelanggan yang didukung oleh iklan dan pelayanan pelanggan. Identitas merek ini merupakan penghalang masuk yang tinggi. Akses distribusi juga merupakan hambatan yang cukup serius bagi pendatang baru. Salah satu kunci keberhasilan pemasaran produk susu bayi adalah menyalurkan produk sedekat mungkin kepada calon pelanggan. Hal 
ini membutuhkan komitmen dari saluran distribusi yang ada. Para distributor akan sangat selektif dalam menyalurkan produkproduk barunya yang belum dikenal. Pendatang baru harus dapat bersaing dalam memperebutkan tempat tersebut dan hal ini membutuhkan biaya yang sangat mahal.

Hambatan lain bagi pendatang baru dalam industri susu adalah besarnya modal yang dibutuhkan dalam investasi. Industri susu dan makanan bayi merupakan industri padat modal, terutama dikaitkan dengan teknologi yang digunakan. Untuk investor asing, hambatan ini mungkin dapat diatasi dengan cara kerjasama atau membeli yang sudah ada. Untuk pemain lokal, hal tersebut sulit dilakukan. Dari penjelasan di atas dapat disimpulkan bahwa hambatan masuk dalam industri ini cukup kuat. Dengan kata lain, kemungkinan masuknya pemain baru sangat kecil.

\section{Persaingan antar produsen dalam negeri (rivarly among existing firms)}

Tingkat pertumbuhan industri susu bayi dan susu olahan sebelum krisis ekonomi cukup menarik yaitu $10,7 \%$ per tahun. Krisis ekonomi menyebabkan menurunnya penjualan sehingga tingkat persaingan semakin ketat karena pertumbuhan industri melambat. Jumlah perusahan dalam industri susu bayi dan olahan sebanyak 7 perusahaan. Dari tujuh perusahaan tersebut tercatat 4 di antaranya adalah produsen terbesar yaitu PT. Sari Husada, PT. Nutricia, PT. Nestle, dan PT. Friesche Vlag. Dengan kata lain, industri susu bayi dan olahan bersifat oligopoli sehingga kekuatan untuk memainkan harga relatif lemah. Seringkali para pemain melakukan kerjasama dalam asosiasi susu bayi dan susu olahan sehingga harga jual untuk beberapa jenis produk ditetapkan bersama-sama. Hal ini dilakukan untuk mengurangi terjadinya perang harga di antara para produsen dan tingkat persaingan.

Produsen susu di Indonesia yang cukup besar. Sampai dengan tahun 1999 tercatat sebanyak enam perusahaan dengan kapasitas produksi yang cukup besar. Perusahaan tersebut adalah PT. Friesche Vlag Indonesia, PT. Indomilk, PT. Nestle indonesia, PT Sari Husada, PT Ultra Jaya, dan PT Foremost Indonesia.

Adanya pembebasan penanaman modal asing di dalam negeri dan batasan impor menimbulkan pesaing-pesaing baru dari luar negeri. Masuknya produk susu dan makanan bayi impor saat ini masih tertahan karena nilai tukar rupiah yang masih lemah yang menyebabkan harga susu bayi dan olahan impor mahal. Namun demikian, perlu disadari bahwa produk susu bayi dan susu olahan impor memiliki kualitas yang baik. Diberlakukannya perdagangan bebas memungkinkan pemain internasional dengan mudah memasuki industri di dalam negeri, misalnya New Zealand, Australia dan negara-negara lain yang telah memiliki mitra dengan produsen dalam negeri.

Hambatan keluar (barrier to exit) dari industri ini cukup besar, karena menyangkut modal yang besar, teknologi yang spesifik, alat-alat dan ketrampilan yang spesifik pula. Hambatan keluar yang lain adalah menyangkut keterkaitan antar sumber daya yang sangat luas, dari peternak sapi, koperasi susu, karyawan pabrik, distributor, konsumen dan pemerintah. Hal ini menyebabkan produsen susu bayi dan olahan cenderung bertahan pada bisnisnya.

Penggunaan kapasitas produksi yang belum optimal akan menyebabkan utilisasi yang rendah dan di masa yang akan datang ada kemungkinan persaingan menjadi semakin ketat. Meskipun persaingan saat ini masih tergolong tidak terlalu ketat karena sifat pasar yang oligopoli, di masa yang akan datang persaingan akan semakin kompetitif dan kuat.

\section{PERATURAN DAN KEBIJAKAN PEMERINTAH}

Sebelum terjadinya krisis di Indonesia, pengadaan bahan baku susu bayi dan susu olahan dari luar negeri cukup besar. Hal ini 
disebabkan oleh rendahnya harga bahan baku susu impor. Impor besar-besaran bahan baku susu ini akhirnya justru menimbulkan dampak yang tidak baik bagi produsen dalam negeri karena harga dalam negeri menjadi sangat rendah. Oleh karena itu pemerintah menerapkan rasio impor sebesar $1: 2,25$ sebelum tahun 1990. Selanjutnya pada tahun 1990 rasio tersebut diperbaiki menjadi sebesar $1: 1,29$. Pada tahun 1997, rasio impor ditetapkan sebesar $1: 1,25$. Sejak diberlakukannya rasio impor susu tersebut, setiap Industri Pengolah Susu (IPS) yang mengimpor bahan baku susu wajib melampirkan bukti serap bahwa mereka telah menyerap susu dalam negeri.

Kebijakan pemerintah berkaitan dengan industri susu nasional adalah dikeluarkannya Keppres No.4 tahun 1998 tentang Koordinasi Pembinaan dan Pengembangan Persusuan Nasional. Selanjutnya untuk memperkuat keberadaan industri kecil dan menengah, pemerintah menerbitkan lagi Keppres No. 9 tahun 1998 yang mewajibkan PMA dan PMDN bermitra dengan usaha kecil sebagai tindak lanjut dari Keppres No 31 tahun 1997.

\section{PELUANG INDUSTRI}

Beberapa peluang yang dapat diraih oleh industri susu di Indonesia antara lain: pertama, dimulainya globalisasi dan adanya pasar bebas untuk kawasan ASEAN dan Kawasan Asia Pasifik memberikan peluang bagi tumbuhnya industri susu di Indonesia. Kedua, perbaikan keadaan ekonomi Indonesia setelah krisis akan meningkatkan daya beli masyarakat sehingga daya serap terhadap produk susu bayi dan olahan akan meningkat pula. Ketiga, regulasi pemerintah yang memberikan kemudahan atas impor bahan baku susu akan dapat meningkatkan kapasitas produsen susu dan meningkatkan efisiensi. Keempat, pasar dalam negeri yang masih cukup besar merupakan pasar yang terbuka bagi industri susu baik saat ini maupun masa yang akan datang. Kelima, trend wanita bekerja di Indonesia mengakibatkan semakin banyaknya ibu-ibu yang tidak dapat memberikan ASI secara maksimal sehingga susu formula menjadi alternatif utama. Hal ini merupakan peluang bagi industri susu untuk memproduksi susu formula dengan komposisi yang mendekati ASI. Keenam, perkembangan teknologi akan dapat meningkatkan efisiensi pengolahan susu dan pengembangan produk-produk yang berkualitas.

Indonesia memiliki jumlah penduduk yang sangat besar dan komposisi penduduk yang sebagian besar berada pada usia balita dan anak-anak. Menurut Sensus tahun 1990 usia balita dan anak-anak menempati porsi terbesar dari komposisi penduduk yaitu sebesar 33\%. Kenyataan ini merupakan pangsa pasar yang besar bagi perkembangan industri susu di Indonesia.

Meskipun laju pertumbuhan penduduk mengalami penurunan, jumlah tersebut masih cukup besar. Proyeksi jumlah penduduk sampai tahun 2025 sebagaimana nampak pada tabel 9.

Tabel 9. Proyeksi Pertumbuhan Jumlah Penduduk Indonesia tahun 1995 - 2025 (dalam jutaan )

\begin{tabular}{|l|c|c|c|c|c|c|c|}
\hline & \multicolumn{7}{|c|}{ Tahun } \\
\cline { 2 - 8 } & $\mathbf{1 9 9 5}$ & $\mathbf{2 0 0 0}$ & $\mathbf{2 0 0 5}$ & $\mathbf{2 0 1 0}$ & $\mathbf{2 0 1 5}$ & $\mathbf{2 0 2 0}$ & $\mathbf{2 0 2 5}$ \\
\hline Jumlah penduduk & 194,8 & 209,5 & 222,8 & 235,1 & 245,7 & 254,2 & 261,4 \\
\hline Perempuan & 97,6 & 104,8 & 111,4 & 117,4 & 122,6 & 122,6 & 130,2 \\
\hline Laki-laki & 97,2 & 104,7 & 111,4 & 117,7 & 123,1 & 127,5 & 131,2 \\
\hline
\end{tabular}

Sumber: Lembaga Demografi FEUI, 1995 


\section{PROSPEK INDUSTRI SUSU}

Prospek industri susu masih cukup cerah setelah krisis ekonomi yang melanda Indonesia. Apabila perbaikan ekonomi terus dilakukan, maka pada tahun-tahun yang akan datang pertumbuhan permintaan susu akan semakin meningkat. Angka peningkatan tersebut diperkirakan mencapai $10,7 \%$ per tahunya. Dimasa yang akan datang, pasokan bahan baku susu mnasih akan lebih banyak dari impor. Porsi yang lebih besar ini disebabkan pasokan bahan baku lokal tetap belum dapat memenuhi kebutuhan industri susu bayi dan olahan meskipun sudah diupayakan peningkatan kapasitas produksi susu dalam negeri.

Prospek industri susu yang cukup cerah ini juga didukung dengan semakin berkembangnya inovasi teknologi, termasuk teknologi pengolahan susu yang mengarah kepada efisiensi dan pengembangan produk-produk susu di masa yang akan datang. Perkembangan ini juga tidak terlepas dari pergeseran budaya yang sangat mempengaruhi pola konsumsi masyarakat terhadap susu. Kesadaran akan pemenuhan gizi bagi perkembangan balita akan mendorong tumbuhnya industri susu nasional. Produk-produk susu lanjutan ASI akan memiliki pangsa pasar yang cukup besar.

Kebutuhan untuk susu dengan kualitas tinggi untuk kalangan menengah ke atas diperkirakan akan berkembang pesat. Produkproduk susu dengan komposisi tertentu yang akan meningkatkan kecerdasan anak merupakan produk inovasi yang banyak diminati konsumen. Tingkat pendidikan masyarakat yang semakin meningkat juga akan berdampak positif pada perkembangan industri susu di masa yang akan datang.

Keadaan ekonomi juga berpengaruh terhadap perkembangan industri khususnya industri susu. Hal ini tidak terlepas dari kenyataan bahwa konsumen terbesar susu adalah masyarakat ekonomi menengah ke atas. Makin tinggi tingkat pendapatan maka makin tinggi pula konsumsi susu. Artinya terdapat korelasi positif antara tingkat pendapatan dengan konsumsi susu, termasuk di dalamnya susu bayi.

Meskipun dampak krisis masih terasa sampai sekarang, perekonomian Indonesia sudah mulai membaik sejak tahun 2001 dengan laju pertumbuhan sekitar $5 \%$. Hal ini tidak terlepas dari upaya pemerintah menarik investor ke dalam negeri. Upaya ini terus dilakukan sampai sekarang dan diharapkan mampu mendorong pertumbuhan produksi susu nasional. Kebijakan impor bahan baku susu yang cenderung mengurangi impor menuntut produsen susu segar dalam negeri untuk meningkatkan kapasitas produksinya.

Perkembangan perdagangan luar negeri akan berdampak pada ekonomi dunia termasuk perdagangan di Indonesia. Pertumbuhan ekonomi dunia akan mendorong ekspor secara keseluruhan. Tabel 10 menunjukkan proyeksi pertumbuhan GDP dan ekspor di Asia dan negara-negara maju.

Tabel 10. Proyeksi Pertumbuhan GDP dan Ekspor di Asia dan Negara-Negara Maju

\begin{tabular}{|c|c|c|c|c|c|c|}
\hline \multirow{3}{*}{ Kawasan } & \multicolumn{3}{|c|}{ Pertumbuhan tahunan GDP perkapita } & \multicolumn{3}{|c|}{ Pertumbuhan tahunan ekspor } \\
\hline & \multirow{2}{*}{$\begin{array}{c}\text { Aktual } \\
1970-1990\end{array}$} & \multicolumn{2}{|c|}{ Proyeksi $1994-2010$} & \multirow{2}{*}{$\begin{array}{c}\text { Aktual } \\
1970.1990\end{array}$} & \multicolumn{2}{|c|}{ Proyeksi 1994 - 2010} \\
\hline & & Divergen & Konvergen & & Divergen & Konvergen \\
\hline China & 4,6 & 2,3 & 3,9 & 11,3 & 4,7 & 6,6 \\
\hline Asia Timur & 5,5 & 3,0 & 4.4 & 10,2 & 5,3 & 6,5 \\
\hline Amerika Latin & 1,7 & 1,4 & 3,3 & 2,4 & 3,8 & 7,0 \\
\hline Asia Selatan & 2,0 & 2,4 & 4,0 & 6,3 & 6,6 & 8,9 \\
\hline Negara maju & 1,9 & 1,6 & 2,3 & 1,5 & 2,9 & 3,7 \\
\hline
\end{tabular}

Sumber. Word Development Report 
Melihat data di atas, dapat diketahui bahwa peningkatan perdagangan dunia ditandai dengan pertumbuhan ekspor terutama untuk kawasan Asia baik Asia Selatan, Timur dan China. Meskipun terjadi krisis di Indonesia tahun 1997 sampai dengan tahun 1998, proyeksi tersebut masih akan berlaku mengingat perbaikan ekonomi di Asia yang cukup baik. Perekonomian Asia, menurut PECC diyakini akan mengalami pemulihan setelah krisis mulai tahun 1999. Lebih lanjut, peningkatan akan terjadi pada tahun 2000 menjadi $2,9 \%$ dari $2,6 \%$. Demikian juga untuk pertumbuhan ekspor susu.

Perdagangan susu dunia akan dipengaruhi oleh diberlakukannya pasar bebas di kawasan ASEAN (NAFTA) dan kawasan Asia Pasifik (AFTA) dalam bentuk Common Effective Preferential Tariff Scheme (CEPT) yang bertujuan menghilangkan tarif semua produk manufaktur pada tahun 2003.

Impor susu Indonesia dari sejumlah negara menunjukkan tingginya ketergantungan industri susu nasional pada industri susu di luar negeri. Meskipun nilai impor susu Indonesia mengalami penurunan, tetapi angka tersebut tergolong besar dibandingkan dengan produksi susu nasional. Tabel 11 menyajikan nilai impor susu nasional sampai dengan tahun 1998.

Apabila dibandingkan dengan eksport produk lainnya, baik berupa produk-produk non material food (misalnya kulit) dan komoditas baru seperti daging, eksport susu tergolong cukup besar meskipun masih jauh dari yang diharapkan. Volume eksport susu pada tahun 1996 mencapai 4.978 .300 ton dan mencapai 31.482 .400 ton pada tahun 2000 . peningkatan ini membuktikan bahwa industri susu nasional cukup tangguh dan mampu bersaing dengan produsen susu dari negaranegara lain. Tabel 12 menyajikan perbandingan volume eksport dari berbagai komoditi.

Nilai ekspor susu, menurut data BPS tahun 2000 mencapai 55.080.300 US\$. Nilai ini jaug lebih besar dibanding niali eksport tahun-tahun sebelumnya yang hanya mencapai 6.871 .300 US\$ pada tahun 1996. Bahkan pada tahun 1997, nilai eksport susu mengalami penurunan menjadi hanya sebesar 3.409.100 US\$ akibat krisis ekonomi. Keadaan ekonomi yang mulai membaik pada tahun 1999 mampu meningkatkan eksport susu menjadi sebesar 6.002 .000 US\$. Tabel 13 menyajikan secara lengkap nilai eksport beberapa komoditi Indonesia ke luar negeri.

Tabel 11. Nilai Impor Susu tahun 1998

\begin{tabular}{|c|c|c|c|}
\hline Year & Volume (tons) & Growth (\%) & Value (US\$000) \\
\hline 1992 & 44,321 & - & 77,677 \\
\hline 1993 & 41,796 & -5.7 & 80,646 \\
\hline 1994 & 48,693 & 16.5 & 80,222 \\
\hline 1995 & 65,464 & 34.4 & 143,157 \\
\hline 1996 & 51,705 & -21.0 & 114,432 \\
\hline 1997 & 48,783 & -6.0 & 94,371 \\
\hline 1998 *) & 36,970 & - & 64,643 \\
\hline
\end{tabular}


Tabel 12. Perbandingan Volume Ekspor Susu Tahun 1996-2000 / Trend Volume of Export of Livestock and Livestock Products 1996 - 2000 (Indonesia)

\begin{tabular}{|c|c|c|c|c|c|c|}
\hline \multirow{2}{*}{ No. } & \multirow[t]{2}{*}{ Commodities } & \multicolumn{5}{|c|}{ Volume of Export } \\
\hline & & 1996 & 1997 & 1998 & 1999 & 2000 \\
\hline $\mathbf{I}$ & $\begin{array}{l}\text { CONVENTIONAL } \\
\text { COMMODITIES }\end{array}$ & & & & & \\
\hline 1. & MATERIAL FOOD & & & & & \\
\hline \multirow[t]{3}{*}{2.} & NON MATERIAL FOOD & & & & & \\
\hline & a. Leather (ton) & $2,618.2$ & $9,407.0$ & $36,125.4$ & $39,068.2$ & $43,884.7$ \\
\hline & b. Bone and Home (ton) & $2,954.1$ & 629.0 & 252.0 & $2,800.4$ & $3,777.0$ \\
\hline$\|$ & NEW COMMODITIES & & & & & \\
\hline \multirow[t]{11}{*}{1.} & MATERIAL FOOD & & & & & \\
\hline & a. Meat (ton) & 45.4 & 373.0 & $3,264.9$ & $3,111.3$ & $1,454.2$ \\
\hline & - Bovine & 4.2 & 5.0 & 1.2 & 17.1 & 26.1 \\
\hline & - Goat Sheep & 0.0 & 0.0 & 68.5 & 12.5 & 34.6 \\
\hline & - Pork & 40.9 & 366.2 & 188.7 & 222.4 & 689.7 \\
\hline & - Chicken & 0.3 & 1.8 & $3,006.5$ & $2,859.3$ & 703.8 \\
\hline & b. Pig (head) & $161,900.0$ & $184,900.0$ & $260,000.0$ & $486,600.0$ & $801,300.0$ \\
\hline & $\begin{array}{l}\text { c. Consumption egg }(000 \\
\text { pC) }\end{array}$ & 0.9 & 4.9 & 0.0 & 0.0 & 77.7 \\
\hline & d. Milk (ton) & $4,978.3$ & $1,730.6$ & $2,385.1$ & $2,352.7$ & $31,482.4$ \\
\hline & e. Butter (ton) & 311.5 & $2,728.5$ & $4,936.1$ & $14,562.2$ & $29,171.3$ \\
\hline & f. Cheese (ton) & 17.7 & 9.9 & 167.5 & 13.0 & 21.7 \\
\hline \multirow[t]{6}{*}{2.} & NON MATERIAL FOOD & & & & & \\
\hline & $\begin{array}{l}\text { a. Parent Stock DOC }(000 \\
\text { head) }\end{array}$ & $1,371.4$ & 466.3 & 270.1 & $1,192.4$ & 814.5 \\
\hline & $\begin{array}{l}\text { b. Final Stock DOC }(000 \\
\text { head) }\end{array}$ & - & - & - & - & 255.6 \\
\hline & c. Hatching egg (000 pc) & $\$ 31.2$ & 182.7 & 0.0 & 722.7 & 140.4 \\
\hline & d. Duck feather (ton) & 453.8 & 343.4 & 26.7 & 331.2 & 274.4 \\
\hline & e. Poultry (000 head) & $1,537.8$ & 527.8 & 148.6 & 40.4 & 699.5 \\
\hline 3. & $\begin{array}{l}\text { VETERINARY } \\
\text { MEDICAMENTS (ton) }\end{array}$ & - & - & - & - & 372.5 \\
\hline
\end{tabular}


Tabel 13. Nilai Ekspor Susu Tahun 1996 - 2000 / Trend Value of Export of Livestock and Livestock Products 1996 - 2000 (Indonesia)

\begin{tabular}{|c|c|c|c|c|c|c|}
\hline \multirow[t]{2}{*}{ No. } & \multirow[t]{2}{*}{ Commodities } & \multicolumn{5}{|c|}{ Value of Export (000 US\$) } \\
\hline & & 1996 & 1997 & 1998 & 1999 & 2000 \\
\hline 1 & $\begin{array}{l}\text { CONVENTIONAL } \\
\text { COMMODITIES }\end{array}$ & $32,545.5$ & $32,625.7$ & $79,280.9$ & $63,225.8$ & $87,625.9$ \\
\hline 1. & MATERIAL FOOD & - & - & - & - & $\cdot$ \\
\hline \multirow[t]{3}{*}{2.} & NON MATERIAL FOOD & $32,545.5$ & $32,625.7$ & $79,280.9$ & $63,225.8$ & $87,625.9$ \\
\hline & a. Leather (ton) & $31,369.2$ & $32,188.7$ & $79,208.4$ & $62,729.8$ & $86,404.1$ \\
\hline & b. Bone and Home (ton) & $1,176.3$ & 437.0 & 72.5 & 496.0 & $1,221.8$ \\
\hline II & NEW COMMODITIES & $27,989.8$ & $24,704.2$ & $29,657.2$ & $47,324.4$ & $118,381.0$ \\
\hline \multirow[t]{11}{*}{1.} & MATERLAL FOOD & $25,049.5$ & $23,201.6$ & $29,231.2$ & $46,118.2$ & $110,061.2$ \\
\hline & a. Meat (ton) & 80.3 & $1,372.7$ & $3,682.2$ & $4,229.7$ & $2,001.9$ \\
\hline & - Bovine & 6.1 & 8.0 & 4.1 & 77.1 & 55.5 \\
\hline & - Goat Sheep & 0.0 & 0.0 & 101.3 & 19.6 & 131.7 \\
\hline & . Pork & 65.5 & $1,363.8$ & 239.7 & 220.9 & 516.2 \\
\hline & - Chicken & 8.7 & 0.9 & $3,337.1$ & $3,912.1$ & $1,298.5$ \\
\hline & b. Pig (head) & $17,660.6$ & $16,771.0$ & $17,151.2$ & $24,427.1$ & $33,293.3$ \\
\hline & c. Consumption egg $(000 \mathrm{pc})$ & 0.4 & 2.5 & 0.0 & 0.0 & 198.1 \\
\hline & d. Milk (ton) & $6,871.3$ & $3,409.1$ & $4,289.7$ & $6,002.0$ & $55,080.3$ \\
\hline & e. Butter (ton) & 349.5 & $1,536.3$ & $3,690.7$ & $11,402.7$ & $19,430.0$ \\
\hline & f. Cheese (ton) & 87.4 & 110.0 & 417.4 & 56.7 & 57.6 \\
\hline \multirow[t]{6}{*}{2.} & NON MATERIAL FOOD & $2,940.3$ & $1,502.6$ & 426.0 & $1,206.2$ & $3,012.4$ \\
\hline & $\begin{array}{l}\text { a. Parent Stock DOC (000 } \\
\text { head) }\end{array}$ & $1,231.2$ & 681.8 & $1,618.8$ & $2,396.4$ & $1,809.2$ \\
\hline & $\begin{array}{l}\text { b. Final Stock DOC }(000 \\
\text { head) }\end{array}$ & - & - & - & 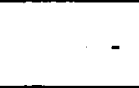 & 147.5 \\
\hline & c. Hatching egg (000 pc) & 56.9 & 34.9 & 0.0 & 206.2 & 54.0 \\
\hline & d. Duck feather (ton) & 548.0 & 547.6 & 222.5 & 666.4 & 210.3 \\
\hline & e. Poultry (000 head) & $2,335.4$ & 920.1 & 203.5 & 333.6 & 791.4 \\
\hline \multirow[t]{2}{*}{3.} & $\begin{array}{l}\text { VETERINARY } \\
\text { MEDICAMENTS (ton) }\end{array}$ & & - & - & & $5,307.4$ \\
\hline & TOTAL & $60,535.3$ & $57,329.9$ & $108,938.1$ & $110,550.2$ & $206,006.9$ \\
\hline
\end{tabular}

Source: Processed Data from Central Bureau of Statistics, 2001 


\section{PEMBENTUKAN STRATEGI KOMPETITIF}

Pada dasarnya mengembangkan strategi kompetitif adalah mengembangkan formula umum mengenai bagaimana bisnis akan bersaing, apa yang seharusnya menjadi tujuannya, dan kebijakan apa yang diperlukan untuk mencapai tujuan-tujuan tersebut (Porter, 1985). Memformulasikan strategi kompetitif adalah menghubungkan industri dengan lingkungan yang ada di sekitarnya. Adanya berbagai tekanan kompetisi dalam industri, maka dapat ditentukan komponen kunci dari industri tersebut. Hal tersebut akan menunjukkan tingkat kekuatan persaingan yang ada di sektor industri serta peluang industri dalam memperoleh tingkat keuntungan.

Industri susu di Indonesia yang cukup prospektif dilihat dari peluang dan ancaman sebagaimana telah dijelaskan pada pembahasan sebelumnya. Hal tersebut memerlukan sebuah formulasi strategi yang tepat agar mencapai keunggulan kompetitif. Menurut Porter (1985), terdapat tiga strategi generik yang dapat digunakan untuk memenangkan persaingan dalam industri yaitu low cost, defferentiation, dan focus. Ketiga strategi tersebut secara konsep merupakan strategi yang berlawanan. Artinya jika sebuah organisasi bisnis memilih menggunakan strategi low cost maka akan sangat sulit mengadakan pengembangan bagi produknya (differentiation strategy), begitu pula sebaliknya.

Namun demikian, pada prakteknya, perusahaan dapat menggunakan kedua strategi tersebut secara bersama-sama (simultan

). Helms, et al. (1997), menyatakan bahwa keunggulan kompetitif tidak hanya didasarkan atas efisiensi (strategi low cost) tetapi juga harus dapat mengembangkan produk yang bervariasi (strategi differentiation). Hal ini dapat dilakukan jika perusahaan mampu meningkatkan efisiensi produksi. Industri susu nasional yang bersifat oligopoli sangat berpotensi untuk menerapkan strategi low cost dan diferensiasi secara simultan. Teknologi pengolahan susu yang semakin berkembang memungkinkan perusahaan bekerja pada skala ekonomi sehingga harga pokok produksi dapat ditekan. Masyarakat Indonesia yang sebagian besar berpendapatan menengah ke bawah sangat responsive pada produk-produk dengan harga murah. Segmen masyarakat ekonomi menengah ke bawah ini perlu direspon oleh perusahaan yang ingin memenangkan persaingan dalam industri susu.

Selain menerapkan strategi low cost, perusahaan juga harus dapat mengembangkan produk-produk susu yang bervariatif. Variasi produk dapat didasarkan atas komposisi maupun kelompok pengguna susu. Variasi atas dasar komposisi berhubungan dengan kandungan yang ada dalam produk susu. Sebagai contoh, saat ini banyak produsen susu yang memasukkan unsur DHA yang diyakini dapat meningkatkan kecerdasan otak bagi anak-anak. Komposisi lain yang ditonjolkan misalnya adanya kandungan dalam susu yang mampu menjaga tulang agar tetap kuat. Sedangkan variasi atas dasar kelompok pengguna dapat memanfaatkan komposisi penduduk di Indonesia, baik anak-anak, dewasa, maupun orang tua. Perbedaan golongan usia tersebut memberi peluang bagi industri susu untuk menciptakan produkproduk yang sesuai dengan kelompokkelompok tersebut. Bahkan saat ini sudah banyak produsen susu yang mengkhususkan pada produk susu untuk ibu hamil. Contoh lainnya adalah produk susu khusus untuk manula atau orang tua.

Perusahaan yang ingin memenangkan persaingan pada industri ini harus mampu menerapkan strategi secara simultan. Aspek efisiensi menjadi kunci bagi keberhasilan penerapan strategi secara simultan tersebut. Strategi diferensiasi dan inovasi harus selalu memperhatikan aspek efisiensi. Sebuah strategi akan counterproductive apabila hanya mengadopsi strategi atas biaya pesaing. Dengan demikian keunggulan kompetitif pada 
industri susu di Indonesia tidak hanya didasarkan atas efisiensi (strategi low cost) tetapi juga harus dapat mengembangkan produk-produk yang bervariasi (strategi differentiation)

\section{DAFTAR PUSTAKA}

Biro Pusat Statistik, 2001, www.bps.go.id Direktorat Jendral Peternakan RI, 2001

Holdiko Perkasa Consultant, 2001, www. holdiko. com

Helms, M. Marilyn, Clay Dibrell, dan Peter Wright, 1997, Competitive Strategies and
Business Performance: Evidence from the Adhesives and Sealants Industry, Management Decision, MCB University Press

Lembaga Demografi FEUI, 1995

Porter, M.E., 1985, Competitive Advantage, New York: The Free Press.

Porter, M.E., 1980, Competitive Strategy, New York: The Free Press.

Thompson, Athur A., dan A.J. Strickland III, 2003, Strategic Management: Concepts and Cases, New York: McGraw-Hill, Irwin. 